\title{
16. RADIOLARIAN BIOSTRATIGRAPHY OF THE PHILIPPINE SEA, DEEP SEA DRILLING PROJECT LEG 59
}

\author{
F. Theyer and P. Lineberger, Hawaii Institute of Geophysics, University of Hawaii, Honolulu, Hawaii
}

\section{INTRODUCTION}

Seven holes, located at five sites (Fig. 1), were drilled by the Glomar Challenger in the Philippine Sea during Leg 59 of the IPOD-Deep Sea Drilling Project. As discussed elsewhere in this volume, the primary objective was to discover the structural, tectonic, and petrologic nature of the sea floor at these sites; no major stratigraphic problems were expected in the sedimentary column, and late Eocene was the maximum basement-contact age anticipated.

The drilling results were routine from a biostratigraphic standpoint, although disappointing with regard to radiolarians. Except for Site 448, where a reasonable Miocene biozonation based on these protozoans is feasible, radiolarians are mostly rare or absent in the recovered sediments (Table 1) and their preservation normally poor (generally comparable to Westberg and Riedel's [1978] preservational categories 4 and 5). This meager yield confines the scope of the present study to assessing the stratigraphic ranges of selected radiolarians as summarized in Tables 2 through 6.

Previously published radiolarian work for this general area is reviewed in the reports by Kling (1971) for DSDP Leg 6 and by Ling (1975) for DSDP Leg 31. As well as reaching into more temperate waters, the latter study encountered much richer assemblages than are found at Leg 59 sites.

\section{METHODS}

To prepare the radiolarians for study, the samples were sieved (through a $62-\mu \mathrm{m}$ screen), $\mathrm{CaCO}_{3}$ was dissolved, and they were cleaned with $\mathrm{H}_{2} \mathrm{O}_{2}$. Glass microslides were prepared from the clean residues and examined under a compound microscope. Relative abundances of specimens were estimated by scanning each slide in its entirety and noting the absence or presence of selected species (see Tables 2-6, in which $+=1, \mathrm{R}=2-6, \mathrm{~F}=7-10, \mathrm{C}=11-15, \mathrm{~A}=>15$ specimens per slide). The overall abundance of radiolarians in each sample (Tables 2-6) was estimated subjectively and designated with the following letters: $\mathrm{A}=$ abundant, $\mathrm{C}=$ common, $\mathrm{F}=$ frequent, $\mathrm{R}=$ rare, and $\mathrm{B}=$ barren of radiolarians.

\section{RESULTS}

\section{Radiolarian Stratigraphy of Each Site}

\section{Site 447}

The only radiolarians in sediments recovered from Holes 447 and 447A are a few Cenozoic spumellarians of unknown stratigraphic range. They occur in Samples $6, \mathrm{CC}, 7, \mathrm{CC}$, and $9, \mathrm{CC}$.

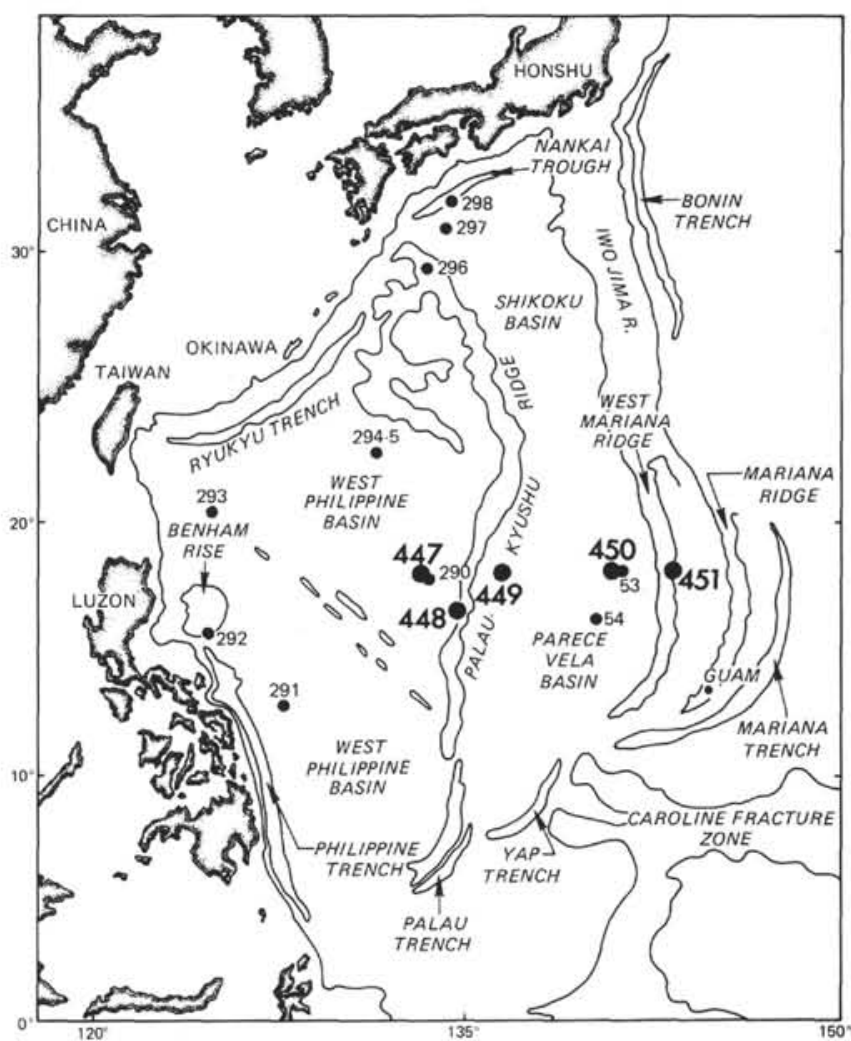

Figure 1. Location map of Holes 447 through 451 drilled during DSDP Leg 59. Other holes were drilled during Legs $6(53,54)$ and 31 (291-298).

\section{Site 448}

Hole 448 (Table 2) yielded the richest radiolarian assemblages of all holes drilled by Leg 59, although even here occurrences are still predominantly labelled "rare" and "common," especially below Core 4 (that is, below a sub-bottom depth of about $35 \mathrm{~m}$ ). Although a continuous middle Miocene to late Oligocene biozonation could be established at this site, beginning with Sample 2-1, 88-92 cm (above which the sediments are barren) and ending with Sample 17,CC (below which the sediments are barren) problems were encountered in the definition of two specific zonal boundaries and zones:

1) The base of the Calocycletta costata Zone, defined by the $C$. costata first appearance datum (FAD), was tentatively placed between Samples 4-2, 70-72 cm and $4-5,77-79 \mathrm{~cm}$, despite the fact that two lower samples $(4, \mathrm{CC}$ and 5,CC also contain this species (Table 
Table 1. Samples found to be barren of radiolarians, DSDP Leg 59.

\begin{tabular}{ll}
\hline Hole & \multicolumn{1}{c}{ Samples (intervals in cm) } \\
\hline 447 & $1, \mathrm{CC}$ \\
$447 \mathrm{~A}$ & $1, \mathrm{CC}, 3, \mathrm{CC}-5, \mathrm{CC}, 8, \mathrm{CC}, 10, \mathrm{CC}-12, \mathrm{CC}$ \\
448 & $1-1,13-15,1, \mathrm{CC}, 2-1,9-11,15-1,52-54,19, \mathrm{CC}, 20, \mathrm{CC}, 21-1,146-150,21, \mathrm{CC}$, \\
& $22, \mathrm{CC}, 23-1,121-122,23, \mathrm{CC} 24, \mathrm{CC}, 25-1,9-15,25, \mathrm{CC}-30, \mathrm{CC}, 32, \mathrm{CC}-35, \mathrm{CC}$ \\
449 & $1, \mathrm{CC}-4, \mathrm{CC}, 5-1,111-113,8, \mathrm{CC}-11, \mathrm{CC}, 13, \mathrm{CC}$ \\
450 & $1, \mathrm{CC}-3, \mathrm{CC}, 6, \mathrm{CC}-8, \mathrm{CC}, 11, \mathrm{CC}-35, \mathrm{CC}$ \\
451 & $4, \mathrm{CC}-8, \mathrm{CC}, 10, \mathrm{CC}, 14, \mathrm{CC}$ \\
\hline
\end{tabular}

2). This was done because there is evidence suggesting that the $C$. costata specimens in the latter two samples are contaminations. Namely, no $C$. costata specimens occur in the two samples $(4-5,77-79 \mathrm{~cm}$ and 5-1, 77-79 $\mathrm{cm})$ that alternate with the suspect samples, and both the Stichocorys wolffii and S. delmontensis Zones, which follow below, would disappear if the C. costata
FAD were to be placed below Sample 5,CC. This in turn would imply that a hiatus of $\sim 3.0 \mathrm{~m}$.y. (Theyer et al., 1978) exists in this upper lower Miocene sedimentary sequence. Such a hiatus is neither supported by the other fossils found in Hole 448 (see Martini, Heiman, and Martini, Heiman, et al., this volume) nor by the radiolarian datum plans and ranges recorded in Table 2. On the contrary, the latter support the position of the $C$. costata zonal boundary as placed.

2) Stratigraphically farther below, the Lychnocanoma elongata FAD (which constitutes the base of the $L$. elongata Zone of the latest Oligocene in low latitudes) also presented problems of definition owing to the peculiar and extreme scarcity of the nominate species. $L$. elongata is normally represented abundantly in latest Oligocene-early Miocene radiolarian assemblages of tropical oceans; further, it is not likely to be very sensitive to corrosion. Nearby Sites 53 and 54 of DSDP Leg

Table 2. Stratigraphy of selected radiolarians in Hole 448, DSDP Leg 59.

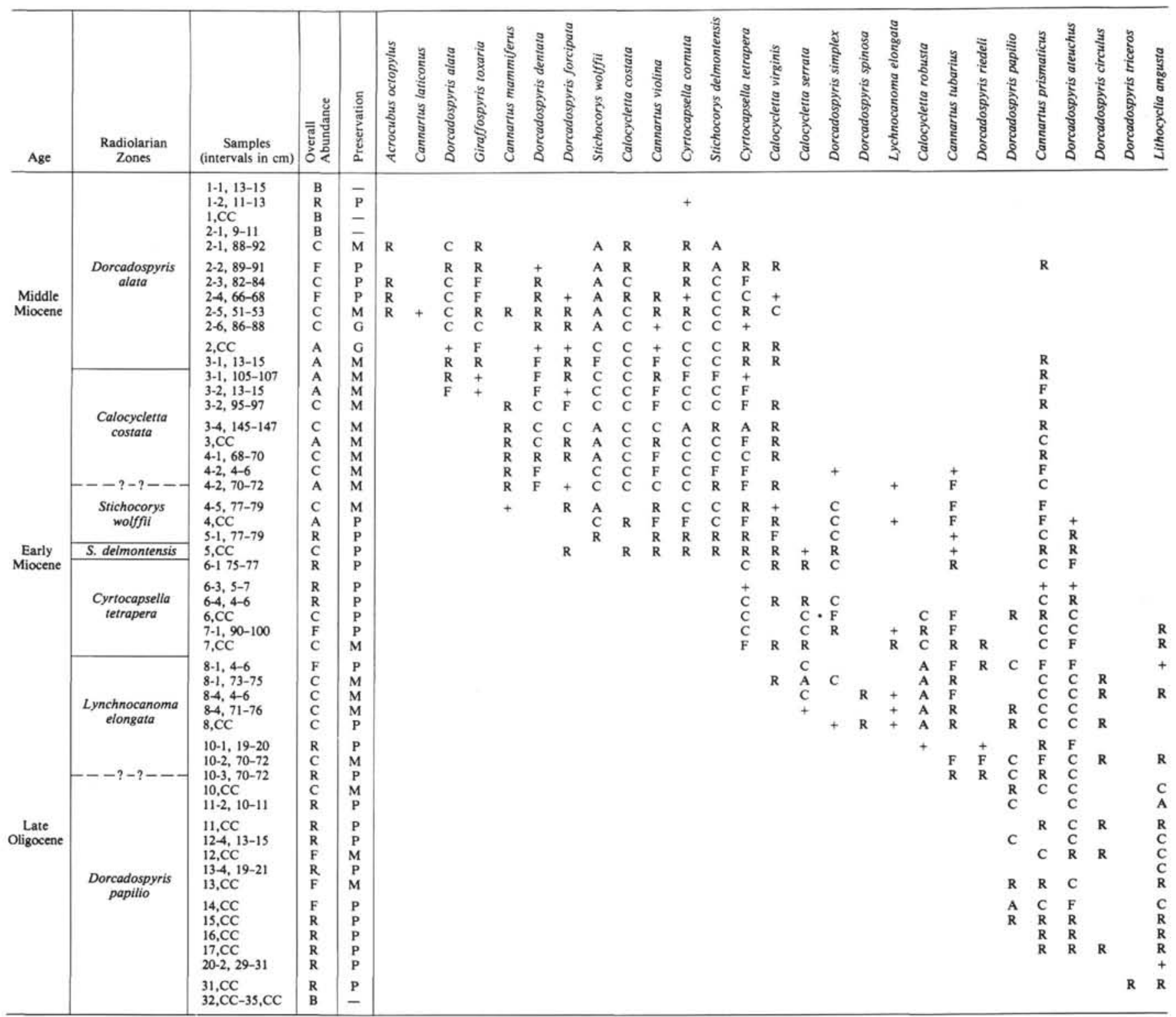

Note: See Methods section for key for Tables 2 through 6. 
6 (Fig. 1) did not yield radiolarians in lower Miocene sediments (Kling, 1971), but Sites 292 and 296 (Leg 31) indicate a similar virtual absence of this guide fossil (Ling, 1975) in otherwise seemingly normal tropical assemblages. Thus, the question arises whether this species, in the present area, was already a very rare form in the Miocene plankton. If so, the L. elongata Zone locally requires amendment to reflect this endemism.

Hole 448A (Table 3 ) clearly ranges from the upper Oligocene (Core 4) into the middle Miocene (in the middle of Core 1). The species present do not, however, allow a recognition of the zones normally found in this interval (Riedel and Sanfilippo, 1971), although Moore's (1971) Dorcadospyris papilio Zone (latest Oligocene) is recognizable in Cores 3 and 4.

\section{Site 449}

Table 4 shows a meager Quaternary assemblage in Sample $2-1,44-46 \mathrm{~cm}$, followed by barren sediments below. Cores 5 through 8 contain mid-Miocene sediments in which the boundary between the Calocycletta costata and Dorcadospyris alata Zones can be recognized. Core 12 contains an early Miocene assemblage.

Table 3. Stratigraphy of selected radiolarians in Hole 448A, DSDP Leg 59.

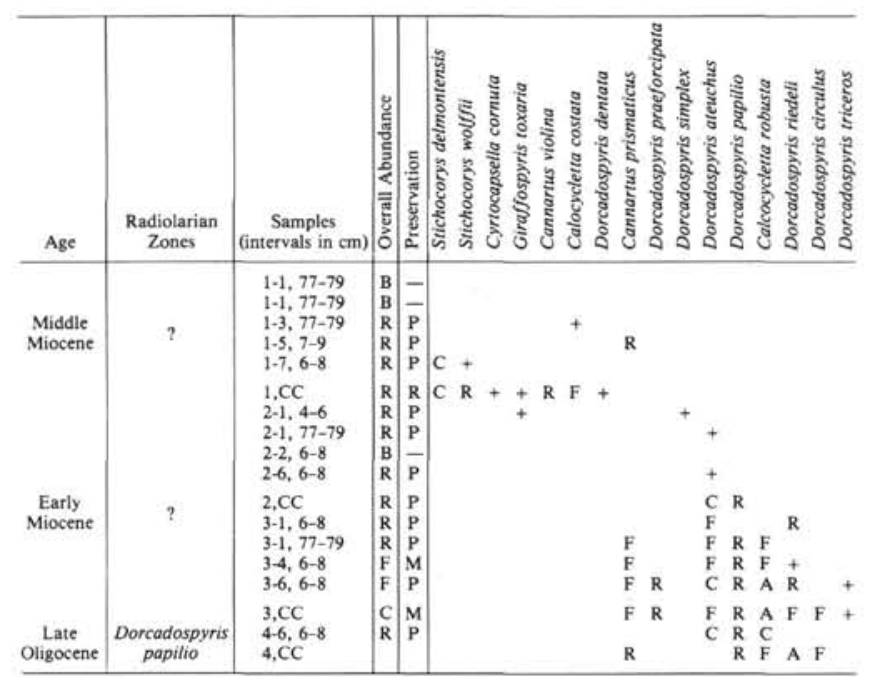

\section{Site 450}

Quaternary radiolarians are found in Sample 1-1, $57-59 \mathrm{~cm}$, and late Miocene assemblages occur in Cores 4 through 5 (Table 5). Barren sediments characterize all remaining cores down-hole.

\section{Site $\mathbf{4 5 1}$}

Table 6 indicates that the site produced a very poor Quaternary fauna in Cores 1 and 3 and barren sediments in the remainder.

\section{Radiolarian Events}

Table 7 presents the levels at which selected species first appear (B) and last occur (T) in the Leg 59 material. These datum levels are defined morphotypically as in Theyer et al. (1978). It must be emphasized that because of the generally poor quality of the material the data are not considered to be very reliable. Finally, very few reworked radiolarians were encountered in the samples from Leg 59.

\section{ACKNOWLEDGMENT}

This research was partially supported by NSF Grant OCE 77-26941. This is Contribution Number 1024 of the Hawaii Institute of Geophysics. The authors thank D. A. Johnson and E. S. Vincent for their comments.

\section{REFERENCES}

Kling, S. A., 1971. Radiolaria: Leg 6 of the Deep Sea Drilling Project. In Fischer, A. G., Heezen, B. C., et al., Init. Repts. DSDP, 6: Washington (U.S. Govt. Printing Office), 1069-1117.

Ling, H. Y., 1975. Radiolaria: Leg 31 of the Deep Sea Drilling Project. In Karig, D. E., Ingle, J. C., Jr., et al., Init. Repts. DSDP, 31: Washington (U.S. Govt. Printing Office), 703-761.

Moore, T., 1971. Radiolaria. In Tracey, J. I., Jr., Sutton, G. H., et al. Init. Repts. DSDP, 8: Washington (U.S. Govt. Printing Office), 947-1058.

Riedel, W. R., and Sanfilippo, A., 1971. Cenozoic radiolaria from the western tropical Pacific. In Winterer, E. L., Riedel, W. R., et al., Init. Repts. DSDP, 7, Pt. 2: Washington (U.S. Govt. Printing Office), 1529-1672.

Theyer, F., Mato, C., and Hammond, S. R., 1978. Paleomagnetic and geochronological calibration of latest Oligocene to Pliocene radiolarian events, Equatorial Pacific. Mar. Micropaleontol., 3: 377-395.

Westberg, M. J., and Riedel, W. R., 1978. Accuracy of radiolarian correlations in the Pacific Miocene. Micropaleontol., 24:1-23. 
Table 4. Stratigraphy of selected radiolarians in Hole 449, DSDP Leg 59.

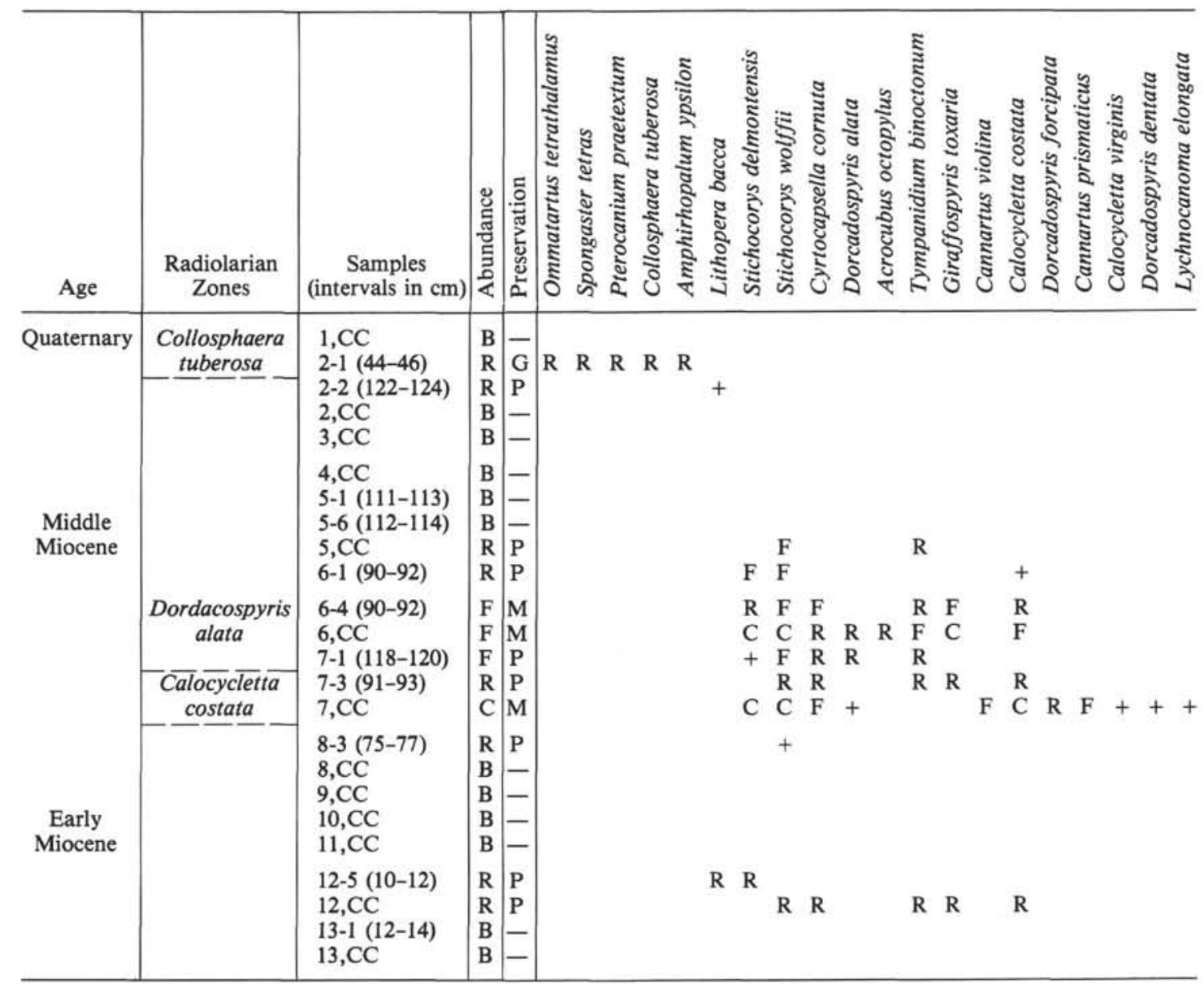

Table 6. Stratigraphy of selected radiolarians in Hole 451, DSDP Leg 59.

Table 5. Stratigraphy of selected radiolarians in Hole 450, DSDP Leg 59.

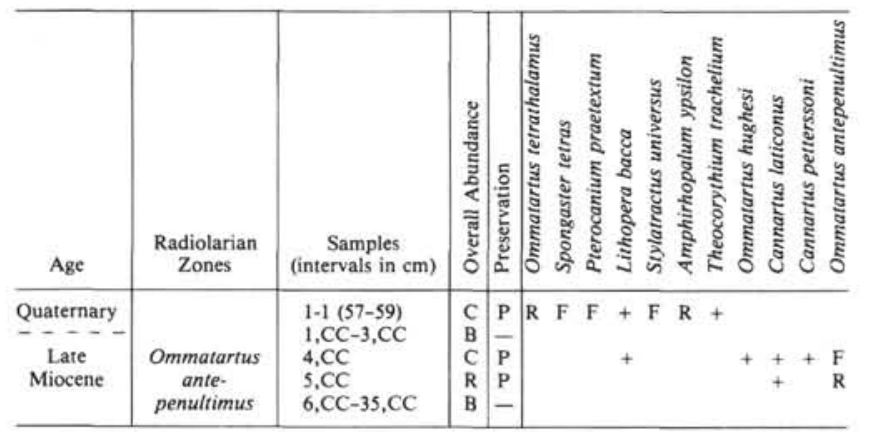

\begin{tabular}{|c|c|c|c|c|c|c|c|c|c|c|}
\hline Age & $\begin{array}{c}\text { Radiolarian } \\
\text { Zones }\end{array}$ & Samples & 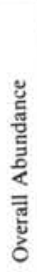 & 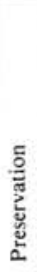 & 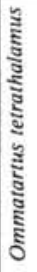 & 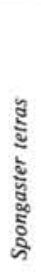 & 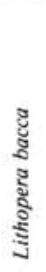 & 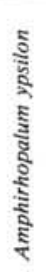 & 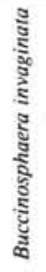 & 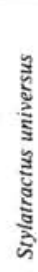 \\
\hline Quaternary & & $\begin{array}{l}1, \mathrm{CC} \\
2, \mathrm{CC} \\
3, \mathrm{CC} \\
4, \mathrm{CC} \\
5, \mathrm{CC} \\
6, \mathrm{CC} \\
7, \mathrm{CC} \\
8, \mathrm{CC} \\
14, \mathrm{CC}\end{array}$ & $\begin{array}{l}\text { C } \\
\text { B } \\
\text { R } \\
\text { B } \\
\text { B } \\
\text { B } \\
\text { B } \\
\text { B } \\
\text { B }\end{array}$ & $\begin{array}{l}\mathrm{M} \\
\bar{M} \\
- \\
- \\
- \\
- \\
-\end{array}$ & R & $\begin{array}{l}\mathrm{F} \\
\mathrm{R}\end{array}$ & $\begin{array}{l}+ \\
+\end{array}$ & $\mathbf{R}$ & F & $\mathrm{F}$ \\
\hline
\end{tabular}


Table 7. Levels of selected radiolarian events, DSDP Leg 59.

\begin{tabular}{|c|c|c|c|c|}
\hline & \multirow[b]{2}{*}{ Radiolarian Events ${ }^{a}$} & \multicolumn{3}{|c|}{$\begin{array}{c}\text { Samples } \\
\text { (intervals in } \mathrm{cm} \text { ) }\end{array}$} \\
\hline & & 448 & $448 \mathrm{~A}$ & 449 \\
\hline $\mathrm{T}$ & Stichocorys delmontensis & $2-1,88-92$ & $1-7,6-8$ & $6-1,90-92$ \\
\hline $\mathrm{T}$ & Stichocorys wolffii & $2-1,88-92$ & $1-7,6-8$ & $5, \mathrm{CC}$ \\
\hline$T$ & Cyrtocapsella cornuta & $1-2,11-13$ & $1, \mathrm{CC}$ & $6-4,90-92$ \\
\hline $\mathrm{T}$ & Dorcadospyris alata & $2-1,88-92$ & & $6, \mathrm{CC}$ \\
\hline $\mathrm{T}$ & Acrocubus octopylus & $2-1,88-92$ & & $6, \mathrm{CC}$ \\
\hline $\mathrm{T}$ & Giraffospyris toxaria & $2-1,88-92$ & $1, \mathrm{CC}$ & $6-4,90-92$ \\
\hline $\mathrm{T}$ & Calocycletta costata & $2-1,88-92$ & $1-3,77-79$ & $6-1,90-92$ \\
\hline $\mathrm{T}$ & Dorcadospyris dentata & $2-2,89-91$ & $1, \mathrm{CC}$ & $7, \mathrm{CC}$ \\
\hline $\mathrm{T}$ & Cyrtocapsella tetrapera & $2-2,88-91$ & & \\
\hline $\mathrm{T}$ & Calocycletta virginis & $2-2,89-91$ & & $7, \mathrm{CC}$ \\
\hline $\mathrm{T}$ & Cannartus prismaticus & $2-2,89-91$ & $1-5,7-9$ & $7, \mathrm{CC}$ \\
\hline $\mathrm{T}$ & Dorcadospyris forcipata & $2-4,66-68$ & & $7, \mathrm{CC}$ \\
\hline $\mathrm{T}$ & Dorcadospyris praeforcipata & & $3-6,6-8$ & \\
\hline $\mathrm{T}$ & Cannartus violina & $2-4,66-68$ & $1, \mathrm{CC}$ & $7, \mathrm{CC}$ \\
\hline $\mathrm{T}$ & Tympanidium binoctonum & & & $5, \mathrm{CC}$ \\
\hline B & Acrocubus octopylus & $2-5,51-53$ & & $6, \mathrm{CC}$ \\
\hline $\mathrm{T}$ & Cannartus mammiferus & $2-5,51-53$ & & \\
\hline B & Dorcadospyris alata & $3-2,13-15$ & & $7, \mathrm{CC}$ \\
\hline B & Giraffospyris toxaria & $3-2,13-15$ & $2-1,4-6$ & $12, \mathrm{CC}$ \\
\hline $\mathrm{T}$ & Dorcadospyris simplex & $4-2,4-6$ & $2-1,4-6$ & \\
\hline $\mathrm{T}$ & Cannartus tubarius & $4-2,4-6$ & & \\
\hline B & Dorcadospyris dentata & $4-2,70-72$ & $1, \mathrm{CC}$ & $7, \mathrm{CC}$ \\
\hline $\mathrm{T}$ & Lychnocanoma elongata & $4-2,70-72$ & & $7, \mathrm{CC}$ \\
\hline B & Cannartus mammiferus & $4-5,77-79$ & & \\
\hline $\mathrm{T}$ & Dorcadospyris ateuchus & $4, \mathrm{CC}$ & $2-1,77-79$ & \\
\hline B & Stichocorys wolffii & $5-1,77-79$ & $1, \mathrm{CC}$ & $12, \mathrm{CC}$ \\
\hline B & Dorcadospyris forcipata & $5, \mathrm{CC}$ & & $7, \mathrm{CC}$ \\
\hline B & Calocycletta costata & $5, \mathrm{CC}$ & $1, \mathrm{CC}$ & $12, \mathrm{CC}$ \\
\hline B & Cannartus violina & $5, \mathrm{CC}$ & $1, \mathrm{CC}$ & $7, \mathrm{CC}$ \\
\hline B & Cyrtocapsella cornuta & $5, \mathrm{CC}$ & $1, \mathrm{CC}$ & $12, \mathrm{CC}$ \\
\hline B & Stichocorys delmontensis & $5, \mathrm{CC}$ & $1, \mathrm{CC}$ & $12-5,10-12$ \\
\hline B & Tympanidium binoctonum & & & $12, \mathrm{CC}$ \\
\hline $\mathrm{T}$ & Calocycletta serrata & $5, \mathrm{CC}$ & & \\
\hline $\mathrm{T}$ & Calocycletta robusta & $6, \mathrm{CC}$ & $3-1,77-79$ & \\
\hline $\mathrm{T}$ & Dorcadospyris papilio & $6, \mathrm{CC}$ & $2, \mathrm{CC}$ & \\
\hline $\mathrm{T}$ & Lithocyclia angusta & $7-1,90-100$ & & \\
\hline B & Cyrtocapsella tetrapera & $7, \mathrm{CC}$ & & \\
\hline $\mathrm{T}$ & Dorcadospyris riedeli & $7, \mathrm{CC}$ & $3-1,6-8$ & \\
\hline B & Calocycletta virginis & $8-1,73-75$ & & $7, \mathrm{CC}$ \\
\hline $\mathbf{T}$ & Dorcadospyris circulus & $8-1,73-75$ & $3, \mathrm{CC}$ & \\
\hline $\mathrm{T}$ & Dorcadospyris spinosa & $8-4,4-6$ & & \\
\hline B & Calocycletta serrata & $8-4,71-76$ & & \\
\hline B & Dorcadospyris simplex & $8, \mathrm{CC}$ & $2-1,4-6$ & \\
\hline B & Dorcadospyris spinosa & $8, \mathrm{CC}$ & & \\
\hline B & Lynchnocanoma elongata & $8, C C$ & & $7, \mathrm{CC}$ \\
\hline B & Calocycletta robusta & $10-1,19-20$ & $4, \mathrm{CC}$ & \\
\hline B & Cannartus tubarius & $10-3,70-72$ & & \\
\hline B & Dorcadospyris riedeli & $10-3,70-72$ & $4, \mathrm{CC}$ & \\
\hline B & Dorcadospyris praeforcipata & & $3, \mathrm{CC}$ & \\
\hline B & Dorcadospyris papilio & $15, \mathrm{CC}$ & $4, \mathrm{CC}$ & \\
\hline B & Cannartus prismaticus & $17, \mathrm{CC}$ & $4, \mathrm{CC}$ & $7, \mathrm{CC}$ \\
\hline B & Dorcadospyris ateuchus & $17, \mathrm{CC}$ & $4, \mathrm{CC}$ & \\
\hline B & Dorcadospyris circulus & $17, \mathrm{CC}$ & $3, \mathrm{CC}$ & \\
\hline$T$ & Dorcadospyris triceros & $31, \mathrm{CC}$ & $3-6,6-8$ & \\
\hline B & Lithocyclia angusta & $31, \mathrm{CC}$ & & \\
\hline B & Dorcadospyris triceros & $31, \mathrm{CC}$ & $3, \mathrm{CC}$ & \\
\hline
\end{tabular}

$\mathrm{a}_{\mathrm{T}}=$ top and $\mathrm{B}=$ bottom of range defined morphotypically. 